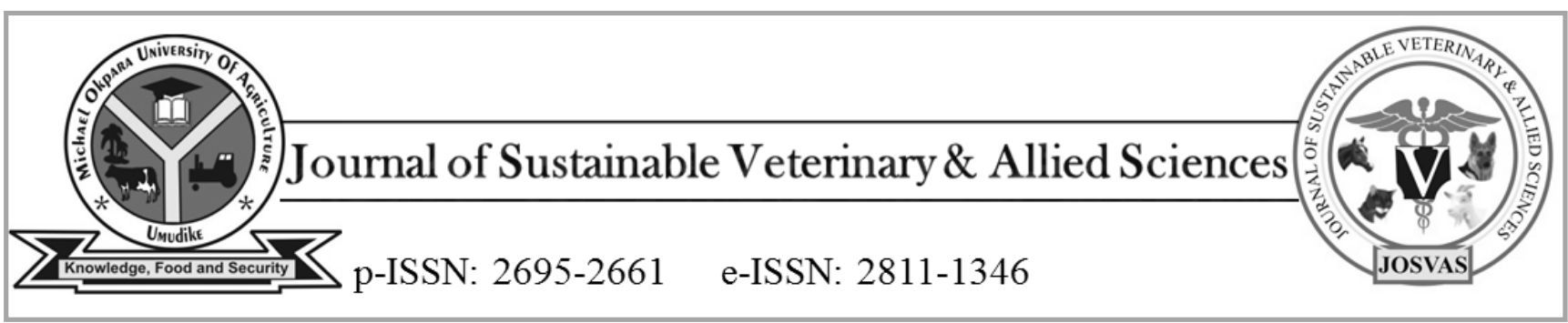

JoSVAS 2021, Vol 1, Issue 1: 25-32

C2021 College of Veterinary Medicine,

Michael Okpara University of Agriculture, Umudike, Nigeria

Original Research Article

\title{
Bacterial pathogens isolated from currency notes circulating amongst live-bird marketers in Damaturu and Potiskum, Yobe State, Nigeria \\ ${ }^{1}$ Ilyasu Y. M., ${ }^{2 *}$ Lawan, A., Chah ${ }^{3}$, K. F. \& ${ }^{4}$ Kazeem, H. M.
}

${ }^{I}$ Ministry of Agriculture and Natural Resources Damaturu, Yobe State ${ }^{2}$ Department of Veterinary Medicine, Faculty of Veterinary Medicine, University of Maiduguri, ${ }^{3}$ Department of Veterinary Microbiology, Faculty of Veterinary Medicine, University of Nigeria, Nsukka ${ }^{4}$ Department of Veterinary Pathology, Faculty of Veterinary Medicine, Ahmadu Bello University Zaria, Nigeria

Corresponding author: drlawan3758@yahoo.com; +2348185089090

\begin{abstract}
Bacterial contamination of currency notes is of veterinary and public health importance because contaminated notes could serve as vector for the spread of pathogenic and perhaps multidrug resistant bacteria. The aim of this study was to assess the antibiotic susceptibility profile of bacterial contaminants found in various denominations of the Nigerian currency circulating among live-bird vendors in Yobe State, Nigeria. Three hundred and twenty (320) currency notes of all denominations were collected from the marketers for investigation. All samples were screened for bacterial pathogens according to standard techniques. The disc diffusion method was used to assess the antibiotic susceptibility of each of the isolated bacterial species against twelve antimicrobial drugs. The result showed that the higher denominations ( $\$ 1000$ - $\$ 100$ ) were contaminated by Bacillus spp, (48.2 \%), Eischerchiia coli ((13.5\%), Klebsiella spp (6.4\%) Pseudomonas aeruginosa (5.0\%), Salmonella spp (0.7\%), Coagulase positive Staphylococcus aureus (17.0\%), and Streptococcus spp (9.2\%) while the lower denominations (\$50 - N5) were contaminated by Bacillus spp (37.1\%), coagulase positive Staphylococcus aureus (19.1\%,), E. coli (14.6 $\%)$, Klebsiella $\operatorname{spp}(5.1 \%)$, P. aeruginosa (6.7\%), Salmonella spp (7.3\%) and Streptococcus spp (10.1\%). All the isolated bacteria were resistant to ampicillin, oxacillin, amoxicillin, and tetracycline. Ciprofloxacin had the greatest activity followed by nitrofurantoin, neomycin, gentamicin, chloramphenicol and streptomycin. The present study revealed that Naira notes circulating among live-bird marketers were contaminated by pathogenic bacteria. It is recommended that live-bird traders should observe strict personal and environmental hygiene while engaging in their daily transaction to forestall any public health threat that may arise from transmission of disease pathogens from the legal tender of transaction in the market.
\end{abstract}

Keywords: Antibiotic, antimicrobial-susceptibility, bacterial pathogens, currency notes, live-bird marketers.

\section{INTRODUCTION}

Between the late 1800s and early 1900s, researchers hypothesized the association of handling money and disease transmission (Horve et al., 2020). Subsequently, through modern scientific techniques, these hypotheses were later confirmed and pathogenic microorganisms were isolated from surfaces of currency notes (Awe et al., 2010; Alemu, 2014). Escherichia coli (E. coli), Pseudomonas aeruginosa (P. aeruginosa), Salmonella spp., and Staphylococcus aureus (S. aureus) are among foodborne pathogenic microorganisms reported on currency notes (Awe et al., 2010). Food pathogens such as E. coli, S. aureus and Salmonella spp. could remain viable for hours or even days post contamination by adhering to various surfaces (Okpala \& Ifeoma, 2019). As currency notes change hands from buyers to the sellers and vice versa, the pathogens on the notes move from one person/location to the other. The continuous transaction and use of currency notes as legal tender in agrofood supply chains are responsible for persistent microbial contamination and proliferation between currency notes and foodstuffs/animal feeds (Thiruvengadam et al., 2014; Agarwal et al., 2015)

Apart from foodstuffs and drinking water, there is a wide range of animal feed and food products that could get 
contaminated by microbial pathogens, acknowledged to be responsible for many foodborne diseases in human (Okpala \& Ifeoma, 2019).

Nigerian currency notes comprise $\mathbf{\$} 1000, \mathbf{\$} 500$, $\$ 200$, $\$ 100, \$ 50, \mathbf{2 0}, \mathbf{1 0}$ and $\mathbf{\$}$ 5 and all serve as legal tender for purposes of settling debts, paying bills, exchange of goods and services, and sometimes given as a gift.

Even though paper currency contains a disinfectant that inhibits the growth of microorganisms during its production at the Central Bank of Nigeria, studies have shown that currency notes serve as fomite for transferring various types of pathogenic microorganisms that include Escherichia coli, Salmonella spp, Staphylococcus aureus, Klebsiella, Pseudomonas aeruginosa, Streptococcus spp (Ahmed et al., 2010; Alemu, 2014; Alabbasy, 2019). Some of these pathogens are known to be important reservoirs for multidrug resistant genes and could therefore transfer them to other pathogens through mobile genetic elements such as plasmids (Walsh \& Fanning, 2008).

The notes become contaminated through various routes due to the ubiquitous nature of microorganisms, their ability to survive on inanimate objects, desiccation and sometimes even disinfectants and in the soil. Poor hands and environmental hygiene at live-birds market (LBMs) are other major sources of contamination of the notes by microorganisms. Other routes of contamination for currencies include the atmosphere during storage (Ejaz et al., 2018), wounds, and counting machines (Agarwal et al., 2015).

Contamination of currency notes is of public health concern since pathogenic microorganisms could be transferred from person to person and over long distances without the knowledge of the handlers. This could lead to illnesses with consequent high morbidity and mortality (Tolba et al., 2007). Many studies have been conducted to investigate presence of bacteria on currency notes in different parts of Nigeria; however, there is dearth of information on this theme in Yobe State. Therefore, the aim of the present study was to investigate the bacterial contaminants on all denominations of Naira notes at live-bird markets and to determine if such bacterial contaminants are multidrug resistant pathogens.

\section{MATERIALS AND METHODS}

\section{STUDY AREA}

The study areas were Potiskum and Damaturu metropolis of Yobe State, North- East Nigeria. The LBMs studied were in Damaturu and Potiskum towns which lie between $11^{\circ} 44^{\prime} 55^{\mathrm{u}}$ North, $11^{\circ} 57^{\prime} 50^{\prime \prime}$ East and $11^{\circ} 42^{\prime} 43^{\prime \prime}$ North, $11^{\circ} 4^{\prime} 11^{\prime \prime}$ East respectively (Figure I). Damaturu is the administrative capital of Yobe State covering a land area of 2,366 km $\mathrm{km}^{2}$ with a population of 88,014 . The town of Potiskum is approximately $90 \mathrm{~km}$ to the west of Damaturu. It is the commercial capital of Yobe State with a population of
205,876 in an area of $559 \mathrm{~km}^{2}$, making it the most densely populated town in Yobe State. Agriculture is the main economic activity within the two towns, engaging about $80 \%$ of the entire labour force. The climate and topography of the two areas are conducive for agriculture.

\section{STUDY DESIGN}

This study employed a descriptive cross-sectional design to assess bacterial contamination on the Naira notes in circulation at the LBMs and their antibiotic susceptibility profile.

\section{SAMPLE SIZE AND SAMPLING}

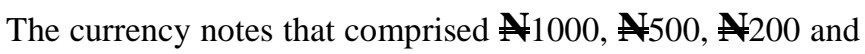
$\$ 100$ were sampled from Damaturu (D作), whereas, the $\mathbf{N}$ 50, 20, $\$ 10$ and $\$ 5$ denominations were sampled from Potiskum (P\$). $\$ 1000-\$ 100$ notes were denoted as higher denomination while $\mathbf{N}$ 50- $\$$ 5 notes were designated as lower denomination notes. The higher denominations are the most widely circulated. A total of 320 Naira notes made of 40 pieces of each denomination were randomly collected from the two markets.

The sample size was determined using the formula below $\mathrm{n}=\mathrm{Z} 2 \mathrm{P}(1-\mathrm{P})$ / L2 (Thrusfield, 2005)

Where $\mathrm{n}$ is the number of individuals, $\mathrm{Z}$ is the score for a given confidence interval

$\mathrm{P}$ is a known or estimated prevalence, $\mathrm{Q}$ is $(1-\mathrm{P})$, and $\mathrm{L}$ is the permissible error of the estimation

In this study, the desired confidence interval is $95 \%$ with an allowable error of estimation of 0.05 and $\mathrm{P}$ was estimated at 92.4\% (Pwaveno et al., 2011)

Therefore $\mathrm{n}=1.962 \times 0.924 \times 0.076 / 0.052$

$=107$

The sample size was adjusted to 320 for precision.

\section{SAMPLE COLLECTION PROCEDURES}

The study used aseptic technique in collecting each Naira note into a separate labelled plastic envelop and sealed. The notes were collected from the LBMs, the processors as well as their customers by exchanging the notes they had with fresh notes from the Central Bank of Nigeria. The period of samples collection was six weeks. A total of 141 higher denominations of the notes were collected from Damaturu LBMs and 178 lower denominations of notes were collected from Potiskum LBMs. 


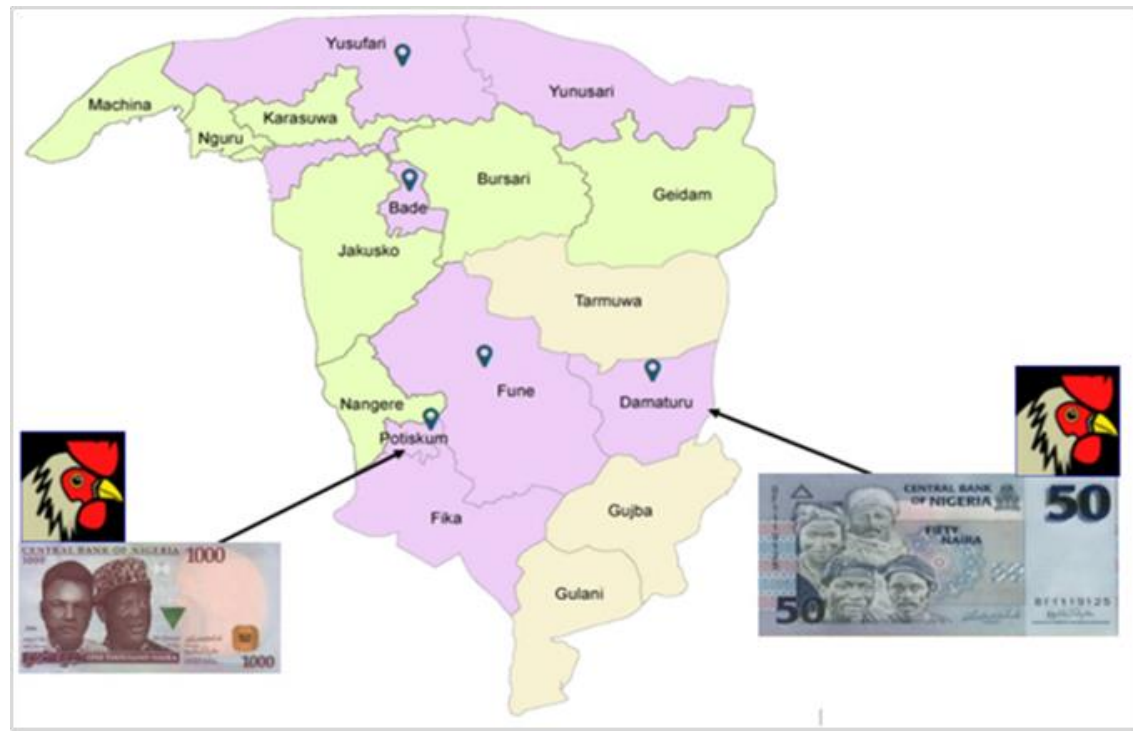

Figure I: Two selected live-birds markets (LBMs) of Damaturu and Potiskum in Yobe State Source- Google

\section{LABORATORY ANALYSIS}

\section{MEDIA USED FOR CULTURE}

The media included Blood agar, Chocolate agar, MacConkey agar (MCA), Mannitol salt agar (MSA), deoxycholate citrate agar (DCA), xylose lysine deoxycholate agar (XLD), Simmons citrate agar, triple sugar iron agar (TSI), selenite broth and peptone water. Mueller-Hinton agar (MHA) was used for the antimicrobial susceptibility test.

\section{SAMPLE PROCESSING}

Each Naira note was given a unique identifier and was processed systematically as illustrated in Figure II. Both surfaces of the note were gently swabbed diagonally with sterile cotton tipped swab moistened in sterile buffered peptone water (BPW). The swab was then plated onto enrichment media such as Blood agar and incubated for 24 hours at $37^{\circ} \mathrm{C}$. The culture plates were then examined for growth and morphologic characteristics based on standard microbiological methods. Discrete colonies were subcultured on Nutrient agar for biochemical analysis and Gram's staining technique (Cheesbrough, 2006).

\section{IDENTIFICATION OF ISOLATES}

The study identified bacterial isolates using standard microbiological methods (Forbes et al., 2007). Gram's staining, colony morphology, and suitable biochemical tests were the methods used for identification of the isolates. Gram positive cocci bacteria were further subjected to catalase and coagulase tests in order to separate catalase positive Staphylococci from catalase negative Streptococci.
Gram negative rods on MCA were grouped into lactose and non-lactose fermenters which are then inoculated into TSI and Indole test as well as citrate test to further aid in identification of different bacteria on the Naira note (Cheesbrough, 2006).

Salmonella spp. colonies were readily identified on XLD while colonies of Staphylococcus species were identified by their characteristics yellow colonies with halo zone on MSA plates. Colonies with pink and reddish purple zones indicated Staphylococcus aureus and S. epidermidis. Coagulase test was used to differentiate between $S$. aureus (coagulase positive) from $S$. epidermidis (coagulase negative). Gram negative bacteria from MCA were subsequently subcultured in TSI and were incubated. Growth with acidic butt, acidic slant, and gas production without hydrogen sulphide (H2S) indicated either E. coli or Klebsiella species. The two isolates were subjected to indole and citrate tests for identification. $E$. coli was identified by its characteristic red ring on the surface of indole, while blue colour change of citrate after incubation confirmed Klebsiella species.

Figure II: Bacteria Isolation, Identification, and Antibiotics susceptibility test. Legends: NA; Nutrient agar, MCA; MacConkey agar, MSa; Mannitol salt agar

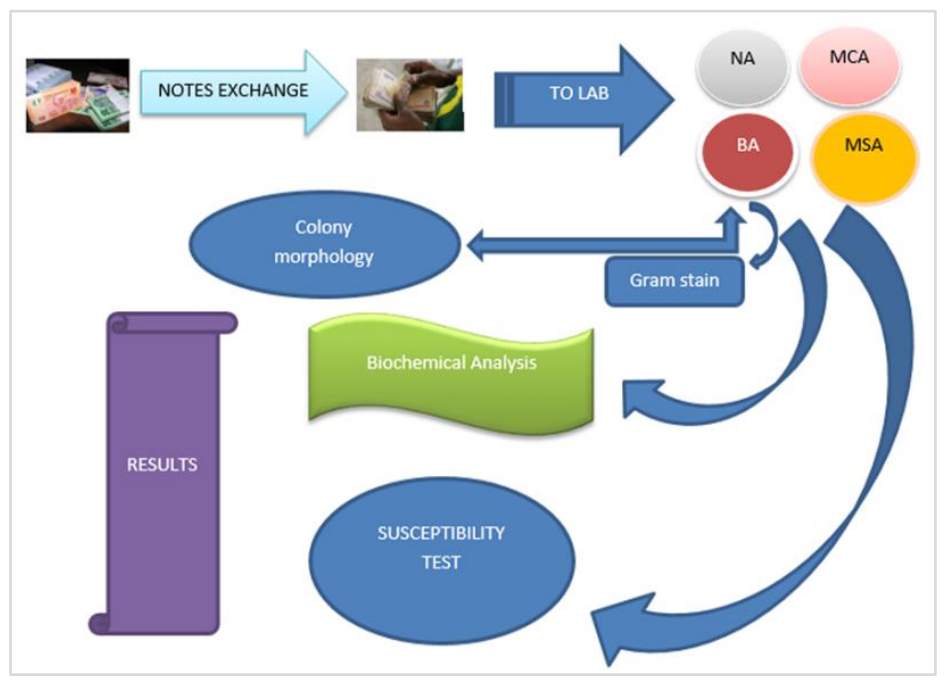

\section{ANTIBIOTIC SUSCEPTIBILITY TESTING (AST)}

Agar diffusion technique on Mueller-Hinton agar (KirbyBauer modified disc diffusion technique) according to CLSI guidelines (Hsueh et al., 2010; Humphries et al., 2018) was used for the antibiotic susceptibility test. The inhibition zone standards for antimicrobial susceptibility were from tables of interpretative zone diameters of Clinical and Laboratory 
Standards Institute (Hindler \& Stelling, 2007). Twelve most commonly used antibiotics were tested. These included ciprofloxacin (CIP), ampicillin (AMP), oxacillin (OX), Nitrofurantoin (F), Neomycin (N), Tetracycline (TE), gentamycin $(\mathrm{CN})$, chloramphenicol $(\mathrm{C})$, Erythromycin $(\mathrm{E})$, Sulphametaxazole/trimethoprim (SXT), amoxicillin (AMC) and streptomycin $(\mathrm{S})$.

\section{DATA ANALYSIS}

Statistical analysis was done using the JMP version 11 software (SAS Institute Inc, Cary, NC). Results were interpreted by descriptive statistics that include frequency and measures of variation while relationship between variables was estimated using Chi-square test at $\mathrm{P} \leq 0.05$ significance level.

\section{RESULTS}

Seven bacterial species were isolated which included Bacillus specie, Coagulase +ve Staphylococcus aureus, Escherichia coli, Klebsiella specie, Pseudomonas aeruginosa, Salmonella specie and Streptococcus specie.

The result showed that the higher denominations (1000$\$ 100$ ) were contaminated by Bacillus spp, (48.2\%), Coagulase positive Staphylococcus aureus (17.0\%), Eischeria coli ((13.5\%), Streptococcus spp (9.2\%), Klebsiella spp (6.4\%) Pasturella aeruginosa (5.0\%), Salmonella spp (0.7\%), and Salmonella spp. $0.7 \%$ with their degree of association indicated by their respective P-values. (Table 1)

The results of prevalence $(\%)$ of the different bacterial species on the lower denominations notes (\$50- N5) sampled from Potiskum are presented in Table 1I. They were contaminated by Bacillus spp $(37.1 \%)$, coagulase positive Staphylococcus aureus (19.1 \%,), E. coli (14.6\%), Streptococcus spp (10.1\%), Salmonella spp (7.3\%), P. aeruginosa (6.7\%) and Klebsiella spp (5.1\%).

Table I: Prevalence and Association of Different Bacterial Species on the Different Currency Notes used in LiveBirds Markets in Damaturu Town of Yobe State, Nigeria

\begin{tabular}{|c|c|c|c|c|c|c|c|c|}
\hline & \multicolumn{8}{|c|}{ Bacteria } \\
\hline Currency & $\begin{array}{l}\text { Bacillus } \\
\text { spp }\end{array}$ & $\begin{array}{l}\text { Coagulase +ve } \\
\text { S. aureus }\end{array}$ & E. coli & Klebsiella & P. aeruginosa & $\begin{array}{l}\text { Salmonella } \\
\text { spp }\end{array}$ & $\begin{array}{l}\text { Streptococcus } \\
\text { spp }\end{array}$ & $\begin{array}{l}\text { Total } \\
\text { Responses }\end{array}$ \\
\hline \multirow{4}{*}{$\begin{array}{c}\mathrm{D}=1000 \\
\text { P-Value }\end{array}$} & 18 & 3 & 4 & 1 & 0 & 0 & 4 & \multirow{3}{*}{30} \\
\hline & $60.0 \%$ & $10.0 \%$ & $13.3 \%$ & $3.3 \%$ & $0.0 \%$ & $0.0 \%$ & $13.3 \%$ & \\
\hline & 0.3531 & 0.3513 & 0.9831 & 0.5085 & 0.2223 & 0.6446 & 0.4508 & \\
\hline & 18 & 5 & 2 & 2 & 3 & 0 & 2 & \multirow{3}{*}{32} \\
\hline \multirow{3}{*}{$\begin{array}{c}\mathrm{D}=500 \\
\mathrm{P}-\mathrm{N} \text { alue }\end{array}$} & $56.3 \%$ & $15.6 \%$ & $6.3 \%$ & $6.3 \%$ & $9.4 \%$ & $0.0 \%$ & $6.3 \%$ & \\
\hline & 0.5134 & 0.8482 & 0.2655 & 0.9763 & 0.2628 & 0.6338 & 0.5801 & \\
\hline & 18 & 7 & 5 & 3 & 2 & 0 & 3 & \multirow{3}{*}{38} \\
\hline \multirow{3}{*}{$\begin{array}{l}\mathrm{D}=200 \\
\mathrm{P}-\mathrm{Nalue}\end{array}$} & $47.4 \%$ & $18.4 \%$ & $13.2 \%$ & $7.9 \%$ & $5.3 \%$ & $0.0 \%$ & $7.9 \%$ & \\
\hline & 0.9393 & 0.8343 & 0.9575 & 0.7122 & 0.9342 & 0.6037 & 0.7879 & \\
\hline & 14 & 9 & 8 & 3 & 2 & 1 & 4 & \multirow{3}{*}{41} \\
\hline \multirow{4}{*}{$\begin{array}{c}\mathrm{D}=100 \\
\mathrm{P}-\mathrm{Value}\end{array}$} & $43.1 \%$ & $22.0 \%$ & $19.5 \%$ & $7.3 \%$ & $4.9 \%$ & $2.4 \%$ & $9.8 \%$ & \\
\hline & 0.1942 & 0.4442 & 0.2923 & 0.8129 & 0.9802 & 0.1884 & 0.9099 & \\
\hline & 68 & 24 & 19 & 9 & 7 & 1 & 13 & \\
\hline & $48.2 \%$ & $17.0 \%$ & $13.5 \%$ & $6.4 \%$ & $5.0 \%$ & $0.7 \%$ & $9.2 \%$ & 141 \\
\hline
\end{tabular}

Table 1I: Prevalence and Association of Different Bacterial Species on the Different Currency Notes in Live-Birds Markets in Potiskum Town of Yobe State of Nigeria

\begin{tabular}{|c|c|c|c|c|c|c|c|c|}
\hline \multirow[b]{2}{*}{ Currency } & \multicolumn{8}{|c|}{ Bacteria } \\
\hline & $\begin{array}{l}\text { Bacill } \\
\text { us spp }\end{array}$ & $\begin{array}{l}\text { Coagulase } \\
\text { +ve } S . \text { aureus }\end{array}$ & E. coli & Klebsiella & $\begin{array}{l}P . \\
\text { aeruginosa }\end{array}$ & $\begin{array}{l}\text { Salmonella } \\
\text { spp }\end{array}$ & $\begin{array}{l}\text { Streptococcus } \\
\text { spp }\end{array}$ & $\begin{array}{l}\text { Total } \\
\text { Responses }\end{array}$ \\
\hline \multirow[b]{2}{*}{$P \neq 50$} & 16 & 11 & 6 & 2 & 2 & 2 & 4 & \multirow{3}{*}{43} \\
\hline & $37.2 \%$ & $25.6 \%$ & $14.0 \%$ & $4.7 \%$ & $4.7 \%$ & $4.7 \%$ & $9.3 \%$ & \\
\hline \multirow[t]{2}{*}{ P-Value } & 0.9888 & 0.3309 & 0.9108 & 0.9059 & 0.5975 & 0.5199 & 0.8673 & \\
\hline & 16 & 7 & 6 & 2 & 3 & 2 & 5 & \multirow{3}{*}{41} \\
\hline$P \neq 20$ & $\begin{array}{l}39.0 \\
\%\end{array}$ & $17.1 \%$ & $14.6 \%$ & $4.9 \%$ & $7.3 \%$ & $4.9 \%$ & $12.2 \%$ & \\
\hline \multirow[t]{2}{*}{ P-Value } & 0.8379 & 0.7664 & 0.9963 & 0.9595 & 0.8871 & 0.5655 & 0.6749 & \\
\hline & 16 & 7 & 7 & 3 & 4 & 4 & 5 & \multirow{3}{*}{46} \\
\hline $\mathrm{P}=10$ & $34.8 \%$ & $15.2 \%$ & $15.2 \%$ & $6.5 \%$ & $8.7 \%$ & $8.7 \%$ & $10.9 \%$ & \\
\hline \multirow{2}{*}{ P-Value } & 0.7982 & 0.5467 & 0.9137 & 0.6585 & 0.6098 & 0.7268 & 0.8717 & \\
\hline & 18 & 9 & 7 & 2 & 3 & 5 & 4 & \multirow{3}{*}{48} \\
\hline $\mathrm{P}=5$ & $37.5 \%$ & $18.8 \%$ & $14.6 \%$ & $4.2 \%$ & $6.3 \%$ & $10.4 \%$ & $8.3 \%$ & \\
\hline P-Value & 0.9618 & 0.9556 & 0.9966 & 0.7840 & 0.8956 & 0.4248 & 0.6983 & \\
\hline \multirow[t]{2}{*}{ All } & 66 & 34 & 26 & 9 & 12 & 13 & 18 & \multirow[b]{2}{*}{178} \\
\hline & $37.1 \%$ & $19.1 \%$ & $14.6 \%$ & $5.1 \%$ & $6.7 \%$ & $7.3 \%$ & $10.1 \%$ & \\
\hline
\end{tabular}


The susceptibility profiles of the Gram +ve bacterial species isolated from the Naira notes to the twelve antibiotics are presented in Figure III. All the bacteria isolates showed resistance to ampicillin, oxacillin, tetracycline and amoxicillin. All the bacteria species showed high susceptibility to ciprofloxacin, nitrofurantoin, neomycin gentamycin, streptomycin and chloramphenicol. However, while all the isolates showed resistance to erythromycin, streptococcus specie showed intermediate susceptibility response.
The susceptibility profile of the Gram -ve bacterial pathogens isolated from the Naira notes to the twelve antibiotics are presented in Figure IV. All the Gram -ve isolates also showed a high susceptibility response to ciprofloxacin, nitrofurantoin, neomycin, gentamycin, chloramphenicol and streptomycin. All the bacteria species also exhibited resistance to ampicillin, oxacillin, tetracycline, amoxicillin and erythromycin. However, Salmonella specie showed an intermediate response to amoxicillin.

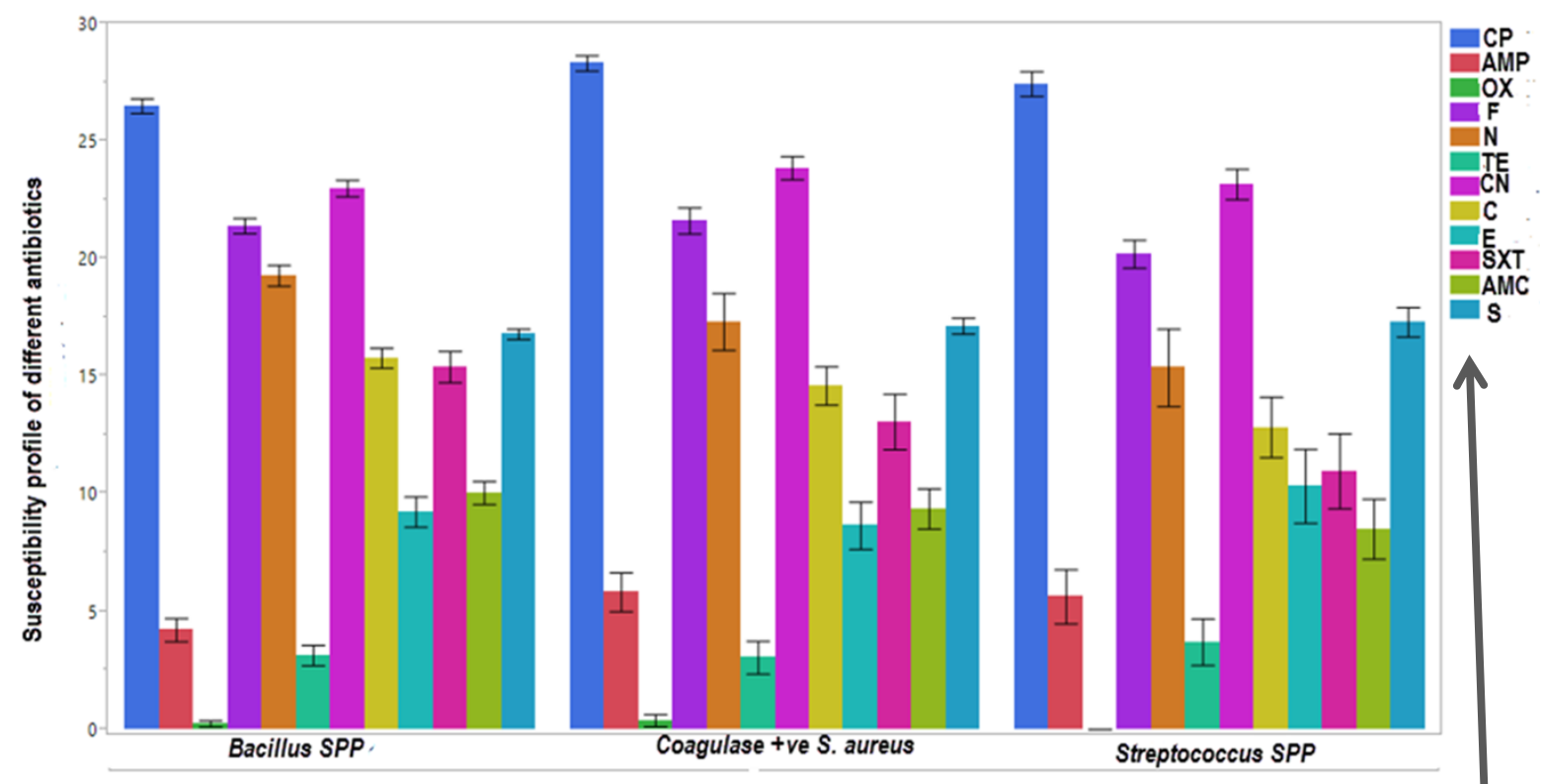

Figure 1II: Gram positive bacteria with their respective susceptibility to different antibiotic in Damaturu and Potiskum, Yobe State

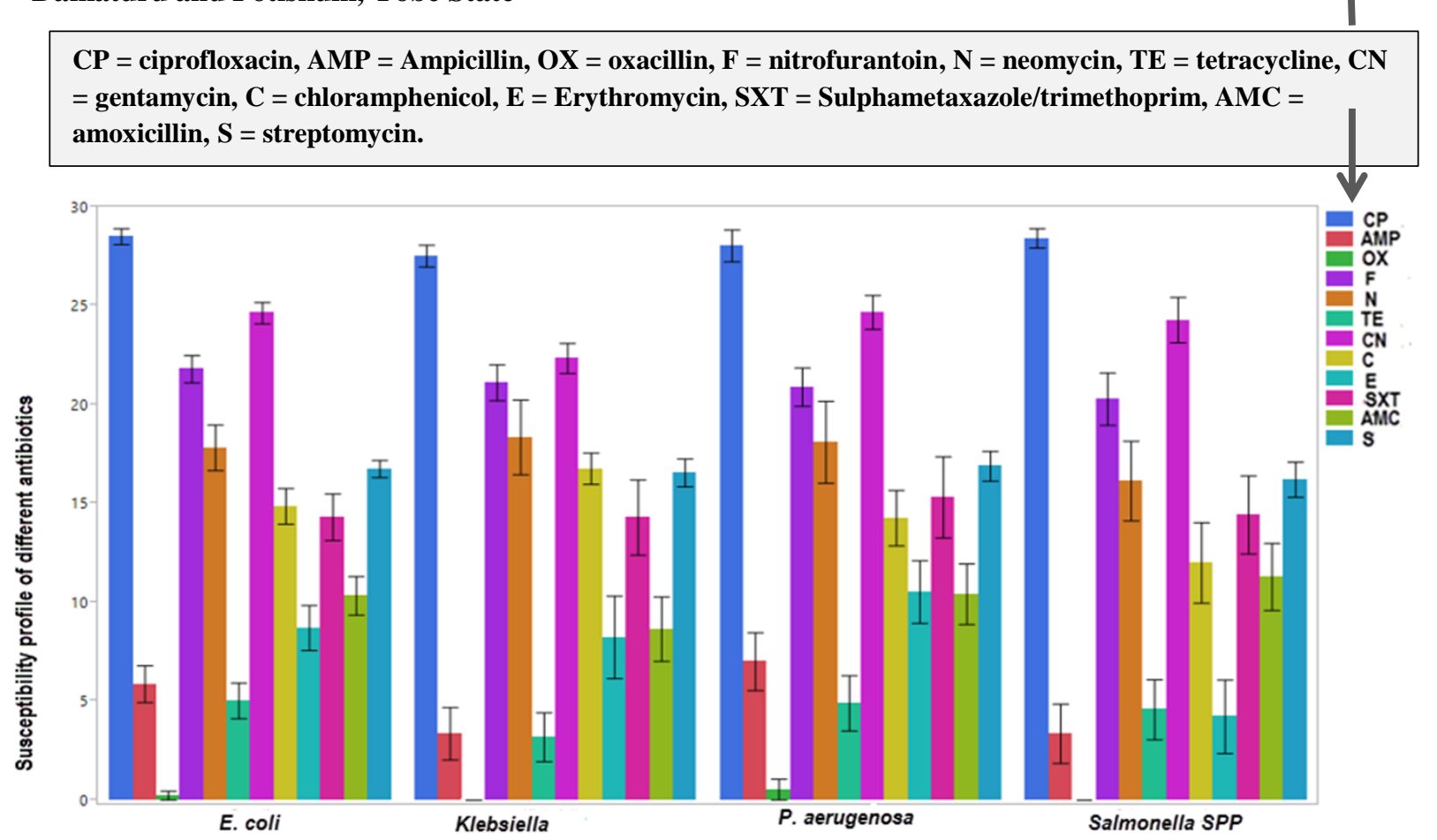

Figure IV: Gram negative bacteria with their respective susceptibility to different antibiotics in Damaturu and Potiskum, Yobe State 


\section{DISCUSSION}

In the present study, nearly all the Naira notes collected from the LBMs in Damaturu and Potiskum towns had bacterial contaminants. These findings are similar to an earlier study conducted on bacterial contaminants of the Naira notes in hospital environments in Kano State (Aminu \& Yahaya, 2018). Other studies have also reported similar findings in Ghana (Tagoe et al., 2010; Dsani et al., 2020), Saudi Arabia (Nasser \& Alwakeel, 2012), United States of America (Pope et al., 2002), Iraq (Moosavy et al., 2013) South Africa (Igumbor et al., 2007) and Nepal (Lamichhane et al., 2009).

Bacillus specie was found to have the highest prevalence across all denominations, with the most contamination (60\%) occurring on the highest denomination note $\$ 1000$, followed by $\$ 500$ notes (56.3\%), $\$ 200$ notes (47.4\%), and $\$ 100$ notes $(43.1 \%)$. The lower denominations of $\$ 50$, $\$ 20$, N10 and $\$ 5$ Naira notes had lower prevalence. Similar result has also been reported by Mailafia et al., (2013) and also by Oluduro et al., (2014). The high prevalence of Bacillus specie could be attributed to its ability to survive for long duration on inanimate objects, soil and fomites, making the specie among the most ubiquitous in the environment. The formation of endospores by Bacillus specie is obviously responsible for its survival on inanimate obecjt and soil as well as ability to withstand common disinfectant.

Apart from Bacillus species, other most predominant bacterial species isolated in the present study include $S$. aureus and E. coli. The presence of $S$. aureus is usually indicative of contamination from the skin, mouth, or nose or due to rubbing off from humans, as the organism is a normal flora of the human body and mucous membranes. Strains of Staphylococcus species especially coagulase +ve S. aureus and even coagulase -ve $S$. aureus can cause several diseases in human (Lakhundi and Zhang, 2018). The clinical significance of $S$. aureus in skin infection, urinary tract infection, toxic shock syndrome, and respiratory tract infection have been reported (Sucilathangam et al., 2016).

Other bacteria species reported in the present study include Klebsiella specie, Salmonella specie and Streptococcus specie. Nearly all of these bacteria have been reported as frequent contaminants of currency notes in other countries (Rote et al., 2010). Klebsiella and Salmonella species were found to contaminate more of the lower denominations notes as indicated in the present study.

The Salmonella species were not found on the higher denominations notes of $\$ 1000, \$ 500$ and $\$ 200$ in the present study but were predominant in the lower denominations notes. This might be attributable to the fact that in the LBMs, the lower denominations are usually handled by the birds' processors when received as charges for processing the birds. Some of their tasks involve defeathering and evisceration of the birds and hence constant contamination of the lower currencies. Additionally, this could be as result of poor hand hygienic practices by the processors and the customers alike, notes could easily get contaminated by these pathogens from human faeces (Elemam et al., 2016). Many Salmonella species are pathogens of animals and human, hence Naira notes transferred from man to man without adequate sanitization or disinfection can act as fomites for the transmission of infectious pathogens.

The presence of Pseudomonas aeruginosa on the Naira could be indicative of faecal contamination. The bacterium is commonly involved in human diseases such as eye and skin infections as well as external ear infections (Barbier et $a l ., 2013)$. It is also a very resilient organism that is capable of withstanding desiccation, disinfection and can also survive on the environment for a long period, and thus, its frequent isolation from currency notes.

The high level of microbial contamination of the Naira notes is a potential hazard to the general public not limited to those that have visited LBMs alone because these Naira noted are continuously in circulation with high possibility of transmitting pathogenic bacteria (Hardy et al.,2006). In the present study, all the bacteria isolated from Naira notes in circulation among the Live-Bird Marketers showed multidrug resistance. This result is at par with reports from earlier studies (Pope et al., 2002; Tagoe et al., 2010). Emergence of multidrug resistance bacteria may be connected with the incessant and indiscriminate incorporation of antibiotics in poultry feed as growth promoters and/or for prophylactic purposes (WHO, 2014). This may also be associated with the presence of mobile genetic elements such as plasmids that could transfer resistance genes through the horizontal gene transfer mechanism (Walsh \& Fanning, 2008).

World Health Organization has reported that thousands of deaths caused by Salmonella spp., E. coli and S. aureus are due to failure of therapy caused by resistance to chemotherapeutic agents (WHO, 2014). The multi-drug resistance observed among the bacteria in the present study further emphasizes the public health significance of the Naira notes. Therefore, it is recommended that live-bird traders and associated workers should observe strict personal and environmental hygiene while engaging in their daily transaction to forestall any public health threat from acquiring or infecting and/or spreading pathogen from the Naira notes. This needs to be supported by the government at the local council level through provision of sanitation points (water points) especially at this point in time when the world is facing pandemic challenge of COVID-19 that have been speculated to originate from animals through wildlife wet market. 


\section{CONFLICT OF INTEREST}

Authors have no conflict to declare.

\section{ACKNOWLEDGEMENT}

We appreciate the patient and diligence of Mallam Baba Fada and Dr. Usman Ali Umaru in the collection of sample from Potiskum and Damaturu live-bird markets respectively. We also want to express gratitude to Mal. Isa Gulani and the entire laboratory staff of the Department of Veterinary Medicine, Faculty of Veterinary Medicine, University of Maiduguri, for their immense contribution towards the successful conduct of this study

\section{REFERENCES}

Abdulla, S. M. (2017). Isolation and Identification of causative agents from some Iraqi Banknote currency. Ibn AL-Haitham Journal for Pure and Applied Science, 26(1), 75-81.

Addo, G. A. N. (2019). Assessing the Impact and Challenges of Mobile Money A Case Study of University of Ghana (Doctoral dissertation, University of Ghana).

Agarwal, G., Ingle, N. A., Kaur, N., Ingle, E., and Charania, Z. (2015). Assessment of microbial contamination of Indian currency notes in Mathura City, India: a cross-sectional study. Journal of Advanced Oral Research, 6(3), 43-48.

Ahmed, M. S. U., Parveen, S., Nasreen, T., and Feroza, B. (2010). Evaluation of the microbial contamination of Bangladesh paper currency notes (Taka) in circulation. Advances in biological research, 4(5), 266-271.

Alabbasy, A. J. (2019). A literature review on microbial contamination of paper currency. International Journal of Electronic Commerce:, 18, 22.

Alemu, A. (2014). Microbial contamination of currency notes and coins in circulation: a potential public health hazard. Biomedicine and Biotechnology, 2(3), 46-53.

Aminu, B. M., \& Yahaya, H. S. (2018). Antibiotic sensitivity pattern of bacteria isolated from Nigerian currencies (Naira) circulating in some hospitals of Kano metropolis, Kano state, Nigeria. Bayero Journal of Pure and Applied Sciences, 11(1), 185-190.

Awe, S., Eniola, K. I. T., Ojo, F. T. \& Sani, A. (2010). Bacteriological quality of some Nigerian currencies in circulation. African Journal of Microbiology Research, 4(21), 2231-2234. Alemu, A. (2014). Microbial contamination of currency notes and coins in circulation: a potential public health hazard. Biomedicine and Biotechnology, 2(3), 4653.

Barbier, F., Andremont, A., Wolff, M. \& Bouadma, L. (2013). Hospital-acquired pneumonia and ventilator-associated pneumonia: recent advances in epidemiology and management. Current opinion in pulmonary medicine, 19(3), 216-228.

Cheesbrough, M. (2006). District laboratory practice in tropical countries, part 2. Cambridge university press.
Dsani, E., Afari, E. A., Danso-Appiah, A., Kenu, E., Kaburi, B. B. \& Egyir, B. (2020). Antimicrobial resistance and molecular detection of extended spectrum $\beta$ lactamase producing Escherichia coli isolates from raw meat in Greater Accra region, Ghana. BMC microbiology, 20(1), 1-8.

Ejaz, H., Javeed, A. \& Zubair, M. (2018). Bacterial contamination of Pakistani currency notes from hospital and community sources. Pakistan journal of medical sciences, 34(5), 1225.

Elemam, M. M., Dhawi, A., Shaban, M. B. \& Dahmani, K. (2016). A study of bacterial contamination on Libyan Paper Banknotes in circulation. American Journal of Microbiology and Biotechnology, 3(1), $1-6$.

Forbes, B. A., Sahm, D. F. \& Weissfeld, A. S. (2007). Diagnostic microbiology (pp. 288-302). St Louis: Mosby.

Hardy, K. J., Oppenheim, B. A., Gossain, S., Gao, F. \& Hawkey, P. M. (2006). A study of the relationship between environmental contamination with methicillin-resistant Staphylococcus aureus (MRSA) and patients' acquisition of MRSA. Infection control and hospital epidemiology, 27(2), 127-132.

Hindler, J. F. \& Stelling, J. (2007). Analysis and presentation of cumulative antibiograms: a new consensus guideline from the Clinical and Laboratory Standards Institute. Clinical infectious diseases, 44(6), 867-873.

Horve, P. F., Lloyd, S., Mhuireach, G. A., Dietz, L., Fretz, M., MacCrone, G. \& Ishaq, S. L. (2020). Building upon current knowledge and techniques of indoor microbiology to construct the next era of theory into microorganisms, health, and the built environment. Journal of exposure science \& environmental epidemiology, 30(2), 219-235.

Hsueh, P. R., Ko, W. C., Wu, J. J., Lu, J. J., Wang, F. D., Wu, H. Y. \& Teng, L. J. (2010). Consensus statement on the adherence to Clinical and Laboratory Standards Institute (CLSI) Antimicrobial Susceptibility Testing Guidelines (CLSI-2010 and CLSI-2010-update) for Enterobacteriaceae in clinical microbiology laboratories in Taiwan. Journal of Microbiology, Immunology and Infection, 43(5), 452-455.

Humphries, R. M., Kircher, S., Ferrell, A., Krause, K. M., Malherbe, R., Hsiung, A. \& Burnham, C. A. D. (2018). The continued value of disk diffusion for assessing antimicrobial susceptibility in clinical laboratories: report from the Clinical and Laboratory Standards Institute Methods Development and Standardization Working Group. Journal of clinical microbiology, 56(8).

Igumbor, E. O., Obi, C. L., Bessong, P. O., Potgieter, N. \& Mkasi, T. C. (2007). Microbiological analysis of banknotes circulating in the Venda region of Limpopo province, South Africa. South African Journal of Science, 103(9-10), 365-366. 
Lakhundi, S. \& Zhang, K. (2018). Methicillin-resistant Staphylococcus aureus: molecular characterization, evolution, and epidemiology. Clinical microbiology reviews, 31(4).

Lamichhane, J., Adhikary, S., Gautam, P., Maharjan, R. \& Dhakal, B. (2009). Risk of handling paper currency in circulation chances of potential bacterial transmittance. Nepal Journal of Science and Technology, 10, 161-166.

Mailafia, S., Michael, O. \& Kwaja, E. (2013). Evaluation of microbial contaminants and antibiogram of Nigerian paper currency notes (Naira) circulation in Gwagwalada, Abuja, Nigeria. Nigerian Veterinary Journal, 34(1).

Moosavy, M. H., Shavisi, N., Warriner, K. \& Mostafavi, E. (2013). Bacterial contamination of Iranian paper currency. Iranian journal of public health, 42(9), 1067.

Nasser, L. A. \& Alwakeel, S. (2012). Bacterial and fungal contamination of Saudi Arabian paper currency and cell phones. Environmental Engineering and Management Journal, 11(3), 72.

Okpala, C. O. R. \& Ifeoma, M. E. (2019). Food hygiene/microbiological safety in the typical household kitchen: Some basic 'Must Know' for the general public. Journal of Pure and Applied Microbiology, 13(2), 697-713.
Oluduro, A. O., Omoboye, O. O., Orabiyi, R. A., Bakare, M. K. \& David, O. M. (2014). Antibiotic resistance and public health perspective of bacterial contamination of Nigerian currency. Advances in Life Science and Technology, 24, 4-9.

Pwaveno, H.B. \& Arunsi, U.K. (2011). Gastrointestinal parasite infections in one humped camel (Camelusdromedarius) of Nigeria. Vet. Res. Forum, 2(4): $278-881$.

Pope, T. W. C., Ender, P. T., Woelk, W. K., Koroscil, M. A. \& Koroscil, T. M. C. (2002). Bacterial contamination of paper currency. Southern medical journal, 95(12), 1408-1411.

Article history:

Received: May 12, 2021,

Revised: July13, 2021

Accepted: August 10, 2021 